\title{
A mobile genetic element in the SARS-CoV-2 genome is shared with multiple insect species
}

Torstein Tengs ${ }^{1}$, Charles F. Delwiche ${ }^{2}$ and Christine Monceyron Jonassen ${ }^{3 *}$

* - corresponding author

1 - Section of Molecular Toxicology, Department of Environmental Health, Norwegian Institute of Public Health, Norway.

Phone: (+47) 47314850, e-mail: torstein.tengs@ fhi.no

2 - Cell Biology and Molecular Genetics, University of Maryland, College Park, MD 20742 USA.

Phone: +1 (301) 405-8286, email: delwiche@umd.edu

3 - Centre for Laboratory Medicine, Østfold Hospital Trust, Norway.

Phone: (+47) 90734557, e-mail: christine.monceyron.jonassen@so-hf.no 
bioRxiv preprint doi: https://doi.org/10.1101/2020.06.29.177030; this version posted June 29, 2020. The copyright holder for this preprint (which was not certified by peer review) is the author/funder, who has granted bioRxiv a license to display the preprint in perpetuity. It is made available under aCC-BY-NC-ND 4.0 International license.

\begin{abstract}
Unprecedented quantities of sequence data have been generated from the newly emergent severe acute respiratory syndrome coronavirus 2 (SARS-CoV-2), causative agent of COVID19. We document here the presence of $\mathrm{s} 2 \mathrm{~m}$, a highly conserved, mobile genetic element with unknown function, in both the SARS-CoV-2 genome and a large number of insect genomes. Although s2m is not universally present among coronaviruses and appears to undergo horizontal transfer, the high sequence conservation and universal presence of s $2 \mathrm{~m}$ among isolates of SARS-CoV-2 indicate that, when present, the element is essential for viral function.
\end{abstract}




\section{INTRODUCTION}

Single-stranded RNA viruses, such as coronaviruses, are known to have genomes with strong secondary structural features, such as stem-loop regions and pseudoknots. We have previously reported the presence of a 41-43 nucleotide long hairpin-forming element, referred to as stemloop II-like motif (s2m) (Jonassen, et al. 1998), in several families of positive-sense singlestranded RNA ((+)ssRNA virus)) viruses (Tengs, et al. 2013). The molecular structure has been mapped in great detail for SARS-CoV (Robertson, et al. 2005). Its sequence and secondary structure are highly conserved, but the phylogenetic distribution among viral genomes is very patchy. These properties indicate that the sequence is mobile, and, to our knowledge, $\mathrm{s} 2 \mathrm{~m}$ represents the only known example of a genetic element with the ability to move between distantly related viruses. The function and evolutionary origin of $\mathrm{s} 2 \mathrm{~m}$ remains unknown, but the high level of conservation seen even in distantly related viruses despite relatively high overall mutation rates suggests that $\mathrm{s} 2 \mathrm{~m}$ is under strong selection. When comparing s $2 \mathrm{~m}$ motifs from different virus species, there are conserved residues both in loopand base-pairing regions, indicating that there is selective pressure to maintain both the primary and secondary structure. The element is always present near the 3 ' end of the genome, and in all virus families where $\mathrm{s} 2 \mathrm{~m}$ has been reported, there are examples of species carrying two (non-identical) back-to-back copies (Quan, et al. 2010; Tengs, et al. 2013). As noted above, related viruses may lack s $2 \mathrm{~m}$ entirely, but when present, its sequence is always highly conserved.

SARS-CoV-2 (Gorbalenya, et al. 2020) is a member of the SARS-related Sarbecovirus subgenus (Andersen, et al. 2020) and this group of coronaviruses is known to contain s $2 \mathrm{~m}$ (Tengs and Jonassen 2016). The presence of s $2 \mathrm{~m}$ in the SARS-CoV-2 genome (GenBank accession MN908947, position 29727-29768) and other members of this group is probably the result of a single horizontal transfer event, predating the divergence of the SARS-related viruses (Tengs, et al. 2013; Tengs and Jonassen 2016).

\section{MATERIALS AND METHODS}

To characterize the specific genotype of $\mathrm{s} 2 \mathrm{~m}$ found in SARS-CoV-2, BLASTN (Altschul, et al. 1990) was used to search the entire virus section of GenBank using all s2m sequence genotypes reported in the literature $(n=97)$ (Jonassen, et al. 1998; Robertson, et al. 2005; Tengs, et al. 2013; Tengs and Jonassen 2016) as query sequences. To check for the presence 
of s2m motifs in insects, both the TSA and the Whole genome shotgun contigs (wgs) databases were mined using the same approach.

For the phylogenetic analyses, sequences were aligned using the Clustal $\mathrm{W}$ algorithm (Thompson, et al. 1994) and maximum likelihood analysis were performed using MEGA X (Kumar, et al. 2018). The James-Taylor-Thornton (JTT) substitution model was used with gamma distribution (5 categories) and invariable sites. Branch swapping was done using the subtree-pruning-regrafting method with 'very strong' filter.

\section{RESULTS}

A total of $5553 \mathrm{~s} 2 \mathrm{~m}$-containing accessions were identified, representing at least four virus families (Supplementary table 1). As expected, there was significant bias towards SARSCoV-2, with the great majority of the s2m accessions stemming from this species (3984/5553; $72 \%$ ). The s $2 \mathrm{~m}$ genotype found in SARS-CoV-2 contains a $\mathrm{G}>\mathrm{U}$ transversion in position 31 (Figure 1, Figure 2) that is consistent in all available SARS-CoV-2 accessions. This guanine is perfectly conserved outside of the SARS-CoV-2 sequences, with $100 \%$ of the other $\mathrm{s} 2 \mathrm{~m}$ genotypes having a $\mathrm{G}$ in this position (Supplementary table 1, Supplementary table 2).

Two of the s2m virus accessions identified were from a recently published RNA-based invertebrate virosphere project (Shi, et al. 2016). These two highly similar sequences, derived from the virome of the spider species Tetragnatha maxillosa, encode a hypothetical protein immediately upstream of $\mathrm{s} 2 \mathrm{~m}$ that could not readily be identified using protein sequence similarity searches. Protein-protein BLAST searches against the non-redundant (nr) GenBank protein database revealed the two best matching non-viral proteins to be from the insect species winter moth (Operophtera brumata) and bagworm moth (Eumeta japonica). In the $O$. brumata genome sequence, an $\mathrm{s} 2 \mathrm{~m}$ motif could be identified immediately downstream from the stop codon of a 331 amino acid long uncharacterized protein (Supplementary table 2).

TBLASTN search against the insect section of the GenBank Transcriptome Shotgun Assembly (TSA) database identified a total of 92 protein sequences where $>200$ amino acids could reliably be aligned with the $O$. brumata homolog. A phylogenetic analysis of these sequences revealed a complex tree, most likely containing both orthologs and paralogs, but with the $O$. brumata accession and the two spider virus accessions clustering within a wellsupported group comprising primarily lepidopteran species (Supplementary Figure 1). 
A total of 99 putative s2m-containg insect contigs were identified, representing 45 species (Supplementary table 2). Correlating these findings with the tree topology based on the hypothetical $O$. brumata protein, 18/22 of the insect accessions in the $O$. brumata cluster were found to originate from s2m-carrying insect species (Supplementary Figure 2). None of the accessions outside this cluster showed any traces of $\mathrm{s} 2 \mathrm{~m}$. Conversely, proteins encoded by the s2m-containing contigs could reliably be matched with the $O$. brumata protein for $50(51 \%)$ of the accessions (Supplementary table 2).

A phylogenetic analysis focusing on $\mathrm{s} 2 \mathrm{~m}$ accessions and using the longest and most similar amino sequences obtained from the TSA, wgs and nr databases (Supplementary table 2) gave a topology that was biased towards lepidopteran species (Figure 2B). Translation of both genomic and transcriptomic data in some cases gave reading frames containing several internal stop codons, but amino acid sequences that could still be aligned to (near) full length (Figure 2B, Supplementary table 2).

\section{DISCUSSION}

As SARS-CoV-2 is embedded within the Sarbecoviruses, it is likely that the unique G > U mutation has occurred specifically during the evolution of the current pandemic strain of SARS-CoV (Figure 2C). An Australian isolate with a 10 base deletion in s2m was also discovered (accession MT007544). Intriguingly, the deletion occurred after passaging isolates in Vero cells (Caly, et al. 2020). This could represent an attenuated SARS-CoV-2 strain, as culturing in permissive cell lines may have altered the selective pressure and alleviated the need to maintain a functional version of the motif.

In the four virus families where $\mathrm{s} 2 \mathrm{~m}$ has previously been described, the flanking protein is easily recognizable. The protein found in insect species, as well as the two T. maxillosa viruses, does not appear to have homologs in any of the better-characterized virus groups, nor does it appear to contain any recognizable motifs. A protein secondary structure homology search (Drozdetskiy, et al. 2015) indicated that the $O$. brumata protein may contain an integrase catalytic domain, which would be consistent with the mobile nature of $\mathrm{s} 2 \mathrm{~m}$. We were unable to identify any signature of a retroviral origin of the $\mathrm{s} 2 \mathrm{~m}$ loci in insect genomes, or any other indication of the insect $\mathrm{s} 2 \mathrm{~m}$ contigs being of viral origin. In several of the genomic contigs, the open reading frame (ORF) covering the uncharacterized protein also 
appeared to contain introns, generally considered a hallmark of eukaryotic genes. In addition, PCR and Sanger sequencing was performed to confirm the presence of $\mathrm{s} 2 \mathrm{~m}$ and the upstream ORF in the O. brumata genome (Supplementary figure 2), making it very unlikely that the downloaded sequence data stem from (RNA) viruses and do not represent bona fide insect sequences.

The insect species that contain $\mathrm{s} 2 \mathrm{~m}$ (and the associated protein) are distantly related, indicating either a deep evolutionary origin with multiple losses or that this genetic construct is also a mobile element, perhaps using viruses as a vector (Gilbert and Cordaux 2017). The $T$. maxillosa virus could represent such a vector, albeit no $\mathrm{s} 2 \mathrm{~m}$ sequences or proteins similar to the $O$. brumata protein could be found in any arachnid species using sequence similarity searches. Mobility of genetic elements such as transposable elements (TEs) has previously been reported in insects (Peccoud, et al. 2017), and an analysis of the genomic s2m contigs using the Dfam portal (Hubley, et al. 2016) revealed that several of the accessions had regions with a significant degree of similarity with the long interspersed nuclear element (LINE) L21_Ldor_D, previously reported from butterflies (Ray, et al. 2019). The exact evolutionary link between the xenologs of $\mathrm{s} 2 \mathrm{~m}$ and the unknown protein found in insects and viruses can not be established based on our data. The $\mathrm{s} 2 \mathrm{~m}$ genotypes found in insects and viruses have similar primary sequence profiles, albeit there appear to be some subtle differences (Figure 3).

We believe that the most likely mode of transfer for $\mathrm{s} 2 \mathrm{~m}$ in viruses is through nonhomologous recombination between RNA molecules. Outside the astroviruses, SARS-CoV and SARS-CoV-2 represent the only known examples of s2m-carrying viruses that infect humans, but it seems probable that $\mathrm{s} 2 \mathrm{~m}$ is still evolutionary active and that this element will continue to affect the evolution of (+)ssRNA viruses. Because the clade of $\mathrm{s} 2 \mathrm{~m}$-containing coronaviruses that includes SARS-CoV and SARS-Cov-2 also includes viruses isolated from bat and pangolin, it is unlikely that $\mathrm{s} 2 \mathrm{~m}$ has played a direct role in zoonotic transfer, but its high degree of sequence conservation suggests that it may present a target for therapy, and the presence of closely related systems in insect hosts provides an opportunity to study the biology of this apparent mobile element in relatively tractable experimental systems.

\section{ACKNOWLEDGEMENTS}

The authors would like to thank M.Sc Anbjørg Rangberg (Østfold Hospital Trust) for help with PCR and sequencing and Dr. Snorre Hagen (Norwegian Institute of Bioeconomy 
bioRxiv preprint doi: https://doi.org/10.1101/2020.06.29.177030; this version posted June 29, 2020. The copyright holder for this preprint (which was not certified by peer review) is the author/funder, who has granted bioRxiv a license to display the preprint in perpetuity. It is made available under aCC-BY-NC-ND 4.0 International license.

Research) for providing the Operophtera brumata DNA. This work was supported by the University of Maryland Agricultural Experiment Station (CFD). 
bioRxiv preprint doi: https://doi.org/10.1101/2020.06.29.177030; this version posted June 29, 2020. The copyright holder for this preprint (which was not certified by peer review) is the author/funder, who has granted bioRxiv a license to display the preprint in perpetuity. It is made available under aCC-BY-NC-ND 4.0 International license.

Figure 1. Secondary structure of s2m in SARS-CoV-2 based on SARS-CoV model (Robertson, et al. 2005).

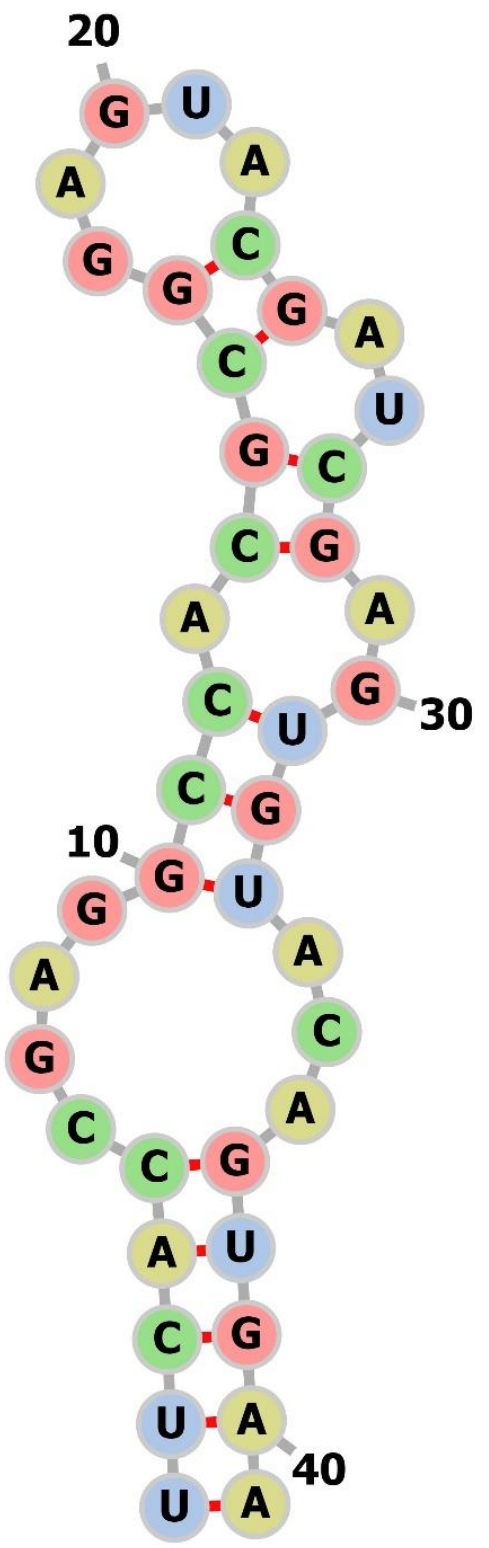


bioRxiv preprint doi: https://doi.org/10.1101/2020.06.29.177030; this version posted June 29, 2020. The copyright holder for this preprint (which was not certified by peer review) is the author/funder, who has granted bioRxiv a license to display the preprint in perpetuity. It is made available under aCC-BY-NC-ND 4.0 International license.

Figure 2. s2m in insects, arachnid viruses and coronaviruses. A) A maximum likelihood analysis was performed on ORF1ab polyprotein sequences from selected coronavirus species. s2m-containing accessions have been highlighted and bootstrap values $>90 \%$ indicated (100 psedoreplicates). B) Maximum likelihood analysis using data from the s2m-associated hypothetical protein (see main text for details). Sequences in boldface stem from reading frames with (multiple) internal stop codons. * - genomic data, ** - accessions without s2m. C) $\mathrm{s} 2 \mathrm{~m}$ sequences corresponding to operational taxonomic units in the phylogenetic trees. Lines above alignment show (non-canonical) base-pairing residues (Robertson, et al. 2005) and the position with the unique $\mathrm{G}>\mathrm{U}$ mutation in SARS-CoV-2 has been indicated. 
bioRxiv preprint doi: https://doi.org/10.1101/2020.06.29.177030; this version posted June 29, 2020. The copyright holder for this preprint (which was not certified by peer review) is the author/funder, who has granted bioRxiv a license to display the preprint in perpetuity. It is made available under aCC-BY-NC-ND 4.0 International license.

A

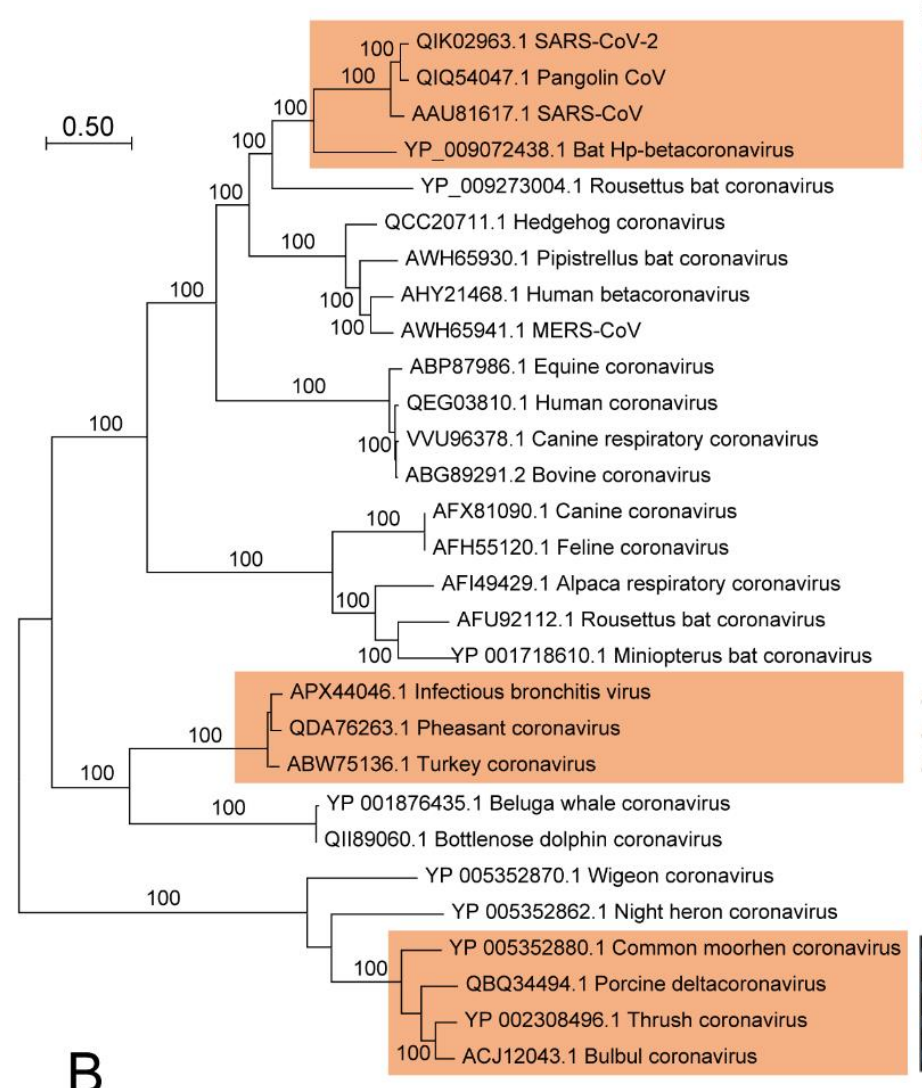

C

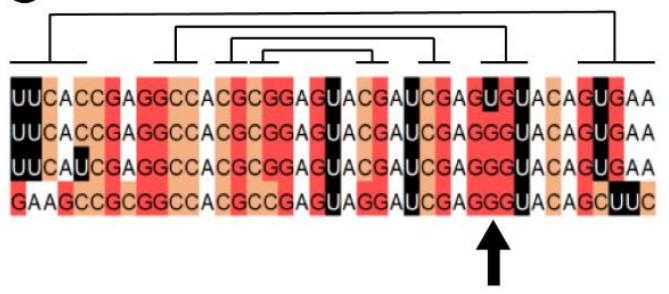

If 1ItIIST

Lepidoptera


bioRxiv preprint doi: https://doi.org/10.1101/2020.06 29.177030; this version posted June 29, 2020. The copyright holder for this preprint (which was not certified by peer review) is the author/funder, who has granted bioRxiv a license to display the preprint in perpetuity. It is made available under aCC-BY-NC-ND 4.0 International license.

Figure 3. DNA logo frequency plot for $\mathrm{s} 2 \mathrm{~m}$ genotypes found in viruses (top panel) and insects (bottom panel). Generated using WebLogo (Crooks, et al. 2004).

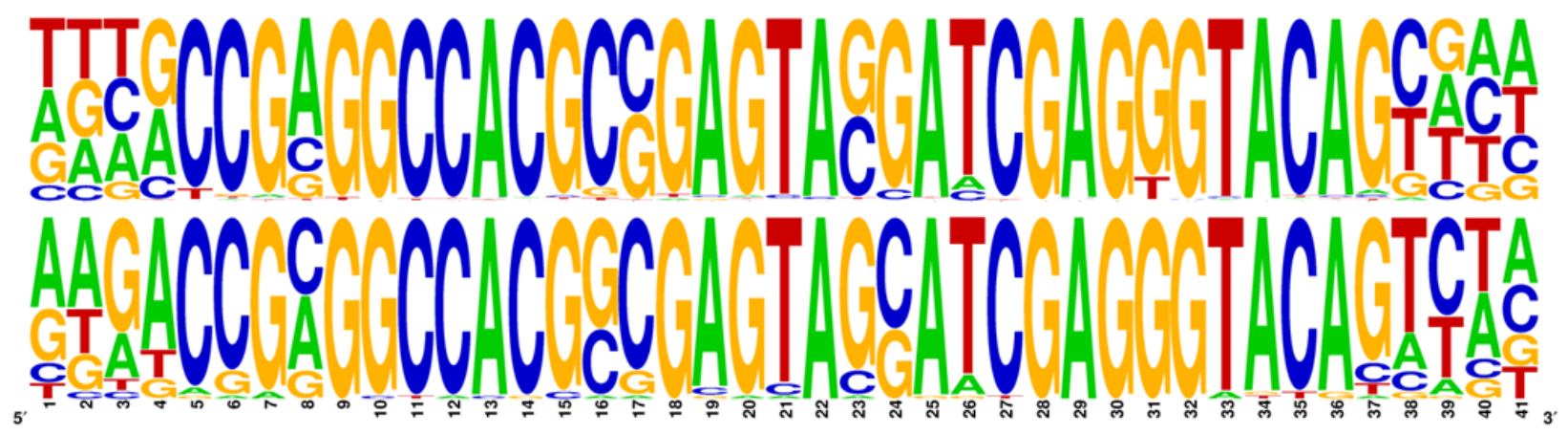


bioRxiv preprint doi: https://doi.org/10.1101/2020.06.29.177030; this version posted June 29, 2020. The copyright holder for this preprint (which was not certified by peer review) is the author/funder, who has granted bioRxiv a license to display the preprint in perpetuity. It is made available under aCC-BY-NC-ND 4.0 International license.

Supplementary Figure 1. Phylogenetic tree based the hypothetical protein found in Operophtera brumata and related insect species. Identical sequences from the same species were removed and a maximum likelihood analysis was performed using MEGA X (Kumar, et al. 2018) after aligning amino acid sequences using the Clustal W algorithm (Thompson, et al. 1994). The James-Taylor-Thornton (JTT) substitution model was used with gamma distribution (5 categories) and invariable sites. Branch swapping was done using the subtreepruning-regrafting method with 'very strong' filter. s2m-containing accessions have been indicated (red: insect species, blue: invertebrate viruses) and bootstrap values $>90 \%$ are shown (100 psedoreplicates). 
bioRxiv preprint doi: https://doi.org/10.1101/2020.06 29.177030; this version posted June 29, 2020. The copyright holder for this preprint (which was not certified by peer review) is the author/funder, who has granted bioRxiv a license to display the preprint in perpetuity. It is made available under aCC-BY-NC-ND 4.0 International license.

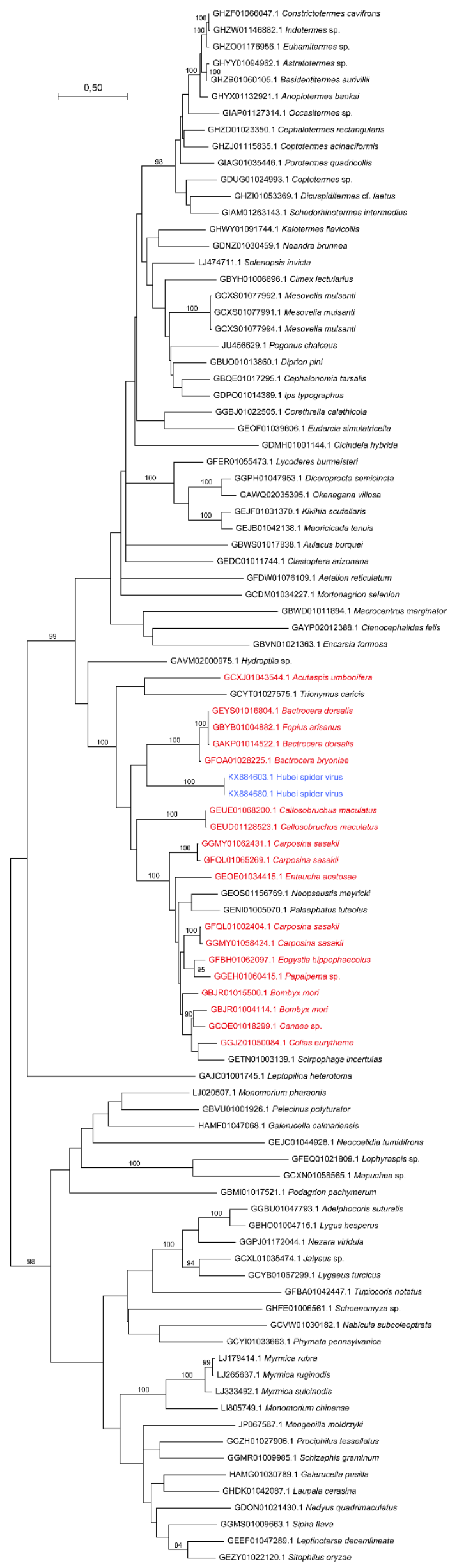


Supplementary figure 2. PCR amplification and Sanger sequencing of the s2m locus in the Operophtera brumata genome. PCR was performed using the AmpliTaq Gold 360 PCR Master Mix (Thermo Fisher Scientific, Oslo, Norway). Primer sequences, ORF stop codon (TAA) and $\mathrm{s} 2 \mathrm{~m}$ sequence have been underlined.

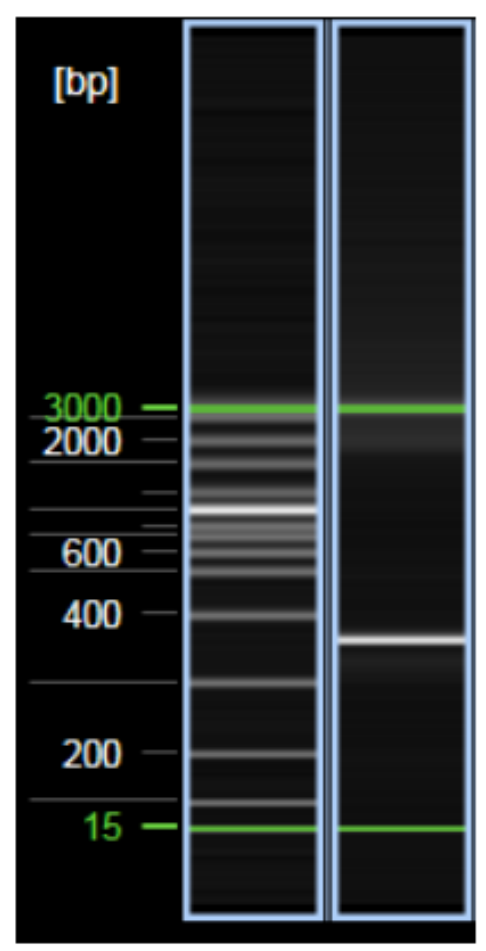

TTTCGTCTCCATTTCCGATTCCCAAAGGAA CAGAACAAACGCAATTGTGCGTCGGATGAT TATCAGCCAACGATAATCAGAACGAATCAA GACCGCGGCCACGGCGAGTAGCATCGAGGG TACAGTCTAGAACCGTTCATTTACTAATTA ACATTAATTAATTAATTTAAGTTTCCATTG TATTTAAAATAAACTTAGCATAGGGGAGCA TTAGTCCGGTCGACACGCATCGTCATTTTA CTCAGTTGTCATAAGTCCTAAACATTTGGT TACAAAATGCAGTGCGGAGTGTGTGGAGCT AATTTTAATGATGGGGTTCAGTGCAGTACC TGTAGCAAACACCTCGATTTTGGT 
bioRxiv preprint doi: https:/doi.org/10.1101/2020.06.29.177030; this version posted June 29, 2020. The copyright holder for this preprint (which was not certified by peer review) is the author/funder, who has granted bioRxiv a license to display the preprint in perpetuity. It is made available under aCC-BY-NC-ND 4.0 International license.

\section{REFERENCES}

Altschul SF, Gish W, Miller W, Myers EW, Lipman DJ. 1990. Basic local alignment search tool. J Mol Biol 215:403-410.

Andersen KG, Rambaut A, Lipkin WI, Holmes EC, Garry RF. 2020. The proximal origin of SARS-CoV-2. Nat Med 26:450-452.

Caly L, Druce J, Roberts J, Bond K, Tran T, Kostecki R, Yoga Y, Naughton W, Taiaroa G, Seemann T, et al. 2020. Isolation and rapid sharing of the 2019 novel coronavirus (SAR-CoV-2) from the first patient diagnosed with COVID-19 in Australia. Medical Journal of Australia.

Crooks GE, Hon G, Chandonia JM, Brenner SE. 2004. WebLogo: a sequence logo generator. Genome Res 14:1188-1190.

Drozdetskiy A, Cole C, Procter J, Barton GJ. 2015. JPred4: a protein secondary structure prediction server. Nucleic Acids Research 43:W389-W394.

Gilbert C, Cordaux R. 2017. Viruses as vectors of horizontal transfer of genetic material in eukaryotes. Current Opinion in Virology 25:16-22.

Gorbalenya AE, Baker SC, Baric RS, de Groot RJ, Drosten C, Gulyaeva AA, Haagmans BL, Lauber C, Leontovich AM, Neuman BW, et al. 2020. The species Severe acute respiratory syndrome-related coronavirus: classifying 2019-nCoV and naming it SARS-CoV-2. Nature Microbiology 5:536-544. Hubley R, Finn RD, Clements J, Eddy SR, Jones TA, Bao W, Smit AF, Wheeler TJ. 2016. The Dfam database of repetitive DNA families. Nucleic Acids Research 44:D81-89.

Jonassen CM, Jonassen TO, Grinde B. 1998. A common RNA motif in the 3 ' end of the genomes of astroviruses, avian infectious bronchitis virus and an equine rhinovirus. Journal of General Virology 79:715-718.

Kumar S, Stecher G, Li M, Knyaz C, Tamura K. 2018. MEGA X: Molecular Evolutionary Genetics Analysis across Computing Platforms. Mol Biol Evol 35:1547-1549.

Peccoud J, Loiseau V, Cordaux R, Gilbert C. 2017. Massive horizontal transfer of transposable elements in insects. Proc Natl Acad Sci U S A 114:4721-4726.

Quan PL, Firth C, Street C, Henriquez JA, Petrosov A, Tashmukhamedova A, Hutchison SK, Egholm M, Osinubi MO, Niezgoda $M$, et al. 2010. Identification of a severe acute respiratory syndrome coronavirus-like virus in a leaf-nosed bat in Nigeria. mBio 1.

Ray DA, Grimshaw JR, Halsey MK, Korstian JM, Osmanski AB, Sullivan KAM, Wolf KA, Reddy H, Foley $\mathrm{N}$, Stevens RD, et al. 2019. Simultaneous TE Analysis of 19 Heliconiine Butterflies Yields Novel Insights into Rapid TE-Based Genome Diversification and Multiple SINE Births and Deaths. Genome Biol Evol 11:2162-2177.

Robertson MP, Igel H, Baertsch R, Haussler D, Ares M, Scott WG. 2005. The structure of a rigorously conserved RNA element within the SARS virus genome. Plos Biology 3:86-94.

Shi M, Lin XD, Tian JH, Chen L, Chen X, Li CX, Qin XC, Li J, Cao JP, Eden JS, et al. 2016. Redefining the invertebrate RNA virosphere. Nature 540:539-543.

Tengs T, Jonassen CM. 2016. Distribution and Evolutionary History of the Mobile Genetic Element $\mathrm{s} 2 \mathrm{~m}$ in Coronaviruses. Diseases 4.

Tengs T, Kristoffersen AB, Bachvaroff TR, Jonassen CM. 2013. A mobile genetic element with unknown function found in distantly related viruses. Virology Journal 10.

Thompson JD, Higgins DG, Gibson TJ. 1994. CLUSTAL W: improving the sensitivity of progressive multiple sequence alignment through sequence weighting, position-specific gap penalties and weight matrix choice. Nucleic Acids Research 22:4673-4680. 